\title{
THE SELECTION OF TEST MATERIALS AND THE REVISION OF THE COLLECTION' S METHOD OF MURINE LEPROSY BACILLUS FOR ITS METABOLIC INVESTIGATIONS
}

\author{
- For Basic Studies on Cultivation of the Human and Murine \\ Leprosy Bacilli (1)
Shinji NISHIMURA, Tonetaro ITO, Tatsuo MORI and Kenji KOSAKA
Department of Leprosy, Research Institute for Microbial Diseases, Osaka University

The selection of laproma for test material of sufficiently active bacilli and a revision of Ito and Sonoda' s collection method for a purer form of the bacillary emulsion were studied for the experiments of the metabolic investigation of murine leprosy bacillus.

The results are summarized below.

1) Leproma in the rat produced 2-3 months after the intratesticular inoculation is most suitable for collecting fresh, active and viable bacilli for metabolic experiments on the murine leprosy bacillus.

2) For testing the purity of the bacillary collection, tissue components without affinity for methylene blue should be detected by dyeing with Nile blue, while some tissue components not stained with Nile blue should be demonstrated by determining of adenosine monophosphatase activity.

3) The Nile blue staining tissue debris in the bacillary fraction can be removed by repeated washing and low speed centrifugation, while the minute particles which show adenosine monophosphatase activity can be taken away be treating with $1 / 8 \mathrm{~N} \mathrm{NaOH}$.

\section{鼠癩菌の物質代謝実験にお汀る集菌}

\section{材料の吟味之集菌法の改良}

一瀨菌，鼠瀨菌の培養に関連した基礎的研究（1）—

西村真二* ・伊藤利浪太郎* ・森 龍男* ・高坂健二*

麻菌の人工培㗅の困難さについてはここに多言を要す るまですないが，瀬問題研究の上からは，菌培養という 困難ではあるが基本的な实験を除外してしまってはこの 問題の徹底した解決は望めないと思う。

わが教室では過去における菌培養の䟞績 ${ }^{1-2-3)}$ を慎重 亿検討し反省を行った結果，現在は培養に関した研究定

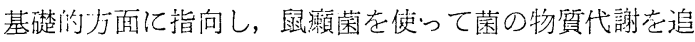
求している。

*大阪大学微生物病研究所癞研究部

(1961年 8 月20日受稿）
さてこの仕專で一番問題となるのは感染組織からの集 菌法であって，策めた菌の理想的な条件としては次のよ うなととが望ましい。

即ち，1）菌が新鮮で活性が商いとと，2）組織成分が 完全に排除されていること，3）分離操作によって必然 的におこる菌自体の物理的または化学的傷害が尠いこ と，4）集菌㽮が菏率であるととなどである。

癩菌，国癩菌を用いる策験のため，最近諸家が行った

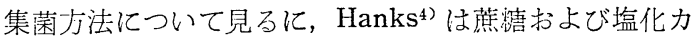
リ溶液を用いた彼自身の方法によって集菌したが，1〜 
2 パーセントの組織成分の混在は避けられなかったと述 べている。中村うは Hanks 法は感染した睪丸組織より 菌を分離するには適しているが, 感染皮下鼠䫝腄を材料 としたときには組彎成分の混入が多くて不適当だと述 べ，彼は鼠癩組織乳剂を0.1パーセントの Trypsin で処 理するととによって組織成分を消化し除去するととに成 功している。Lew and Carpenter ${ }^{6)}$ も加熱した人癩結節 および鼠癩結節乳剂にTrypsin を作用させて消化し， 組織成分の除去に成功している。著者の 1 人伊藤 ${ }^{7-8)}$ は 園田と共に中村の开法にならってTrypsinで組織成分を 除き，高速遠沈 (10.000r.p.m) を繰返し洗涤するととに より純粋な菌を多量に篹め得たと報じ, 更に菌のCatalase 活性が集菌材料である鼠癩堙の新焦か或は嗦旧かに よって著しい差のあるととを警告した。

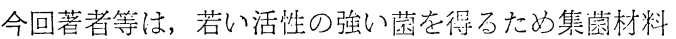
を吟味する上の指標を得ようとして，接種後種々なる洔 期の睪丸鼠㮫腫より菌を集好てれらの呼吸，その他の 生物学的活性を測定しててれが瀬堙の陳旧度との関係を 明かにし，また一方ではさきに発表した伊藤，園四の方 法で集めた菌の純粋度について再検討を行ない，乙の方 法では排除困星であった微量の組織細胞成分をも完全に 除去し得る万法を考案し, 従来の集菌法を改良してほぼ

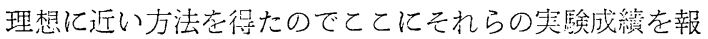
告する。

\section{I 鼠癩腫の陳旧度と菌の生物学的活性}

接種後 2 力月乃至 5 力月のラット睪丸鼠湏腫から得た 菌を村料とし，呼吸，Hydrogen Transfer Capacity (HTC), Catalase 活性市よび Peroxidase 活性を测定 した。

\section{実 験 方 法}

1）供試菌：国癩菌熊本株をラット睪丸内に接種し， 2 力月目， 3 力月目， 4 力月目及び 5 力月目に各々睪丸 を切除し，各時期の睪丸から伊藤，園田 ${ }^{7}$ の方法によっ て集菌した。なお睪丸内に乾酪化病巣が有りや否やにつ いては特に注意を払った。

2）呼吸：菌の呼吸は Warburg 検圧法によって, 菌 の内部呼吸を下記の条件で測定した。

主室：菌浮游液 $1.5 \mathrm{ml}$ (湿菌150mg含有)

$0.2 \mathrm{M} \mathrm{pH7} .2$ phosphate buffer $0.5 \mathrm{ml}$

副室：20\%́ $\mathrm{KOH} 0.2 \mathrm{ml}$

水槽温度： $37.5^{\circ} \mathrm{C}$

3） H T C : 菌のHTCは Thunberg 管を用い嫌気的 に下記の条仵で $37^{\circ} \mathrm{C} ， 3$ 時閻反応させ，還元された一
Triphenyl Formazan を醋酸エチル $5 \mathrm{ml}$ で抽出, 分光 々度計で定量して求めた。

菌浮游液：1.0ml（湿菌 $50 \mathrm{mg}$ 含有）

$0.2 \mathrm{M}$ phosphate buffer: $1.0 \mathrm{ml}$

$1 / 1000 \mathrm{M}$ ラウリン酸: $1.0 \mathrm{ml}$

$1 /{ }_{1000} \mathrm{M}$ Triphenyltetrazolium chloride : $1.0 \mathrm{ml}$

4) Catalase 活性: Catalase 活性は Warburg 検圧 法によって下記の条件で測定した。

主室：菌浮游液 $1.5 \mathrm{ml}$ (湿菌 $50 \mathrm{mg}$ 含有)

$0.3 \mathrm{M} \mathrm{pH} 6.8$ phosphata buffer $0.5 \mathrm{ml}$

側室: $0.075 \mathrm{M} \mathrm{H} \mathrm{H}_{2} \mathrm{O}_{2} 1.0 \mathrm{ml}$

水槽温度: $37.5^{\circ} \mathrm{C}$

5) Peroxidase 活性：Peroxidase活性はHedgecock. Faucher (1958) ${ }^{9)}$ の変法を用いて下記の条件で测定し た。

菌浮游液 $\quad: 1.0 \mathrm{ml}$ (湿菌 $50 \mathrm{mg}$ 含有)

$0.1 \mathrm{M}$ pH6.8 phosphate buffer: $1.0 \mathrm{ml}$

$1 \%$ ó $\quad \mathrm{H}_{2} \mathrm{O}_{2} \quad: 0.5 \mathrm{ml}$

$0.1 \%$ Pyrogallol : $2.5 \mathrm{ml}$

以上を混和 $37.5^{\circ} \mathrm{C}$ の水槽中で 15 分間振擝後 $50 \% \mathrm{H}_{2}$ $\mathrm{SO}_{4} 0.15 \mathrm{ml}, 20 \%$ Vitamin $\mathrm{C} 0.1 \mathrm{ml}$ を加えて反応を停 止, Ether $3 \mathrm{ml}$ で 2 回抽出し, 日立光電分光々度計を用 い(Filter43)，生成された pur purogallin 量を測定した。

\section{実 験 成 績}

1）呼吸および H T C

鼠㵋菌の内部呼吸は表 1 亿示す如く，接種後 2 力月目 の睪丸より集めた菌と 3 力月目睪丸より集めた菌では著 明な差が認められないが，4 力月目睪丸より集めた菌で は明らかに低值を示し， 2 力月目の菌に比し約 $3 / 5$ で， 5 カ月目睪丸より集めた菌は 2 力月目の菌に比し約 $1 / 2$ の值 を示した。特に乾酪化の著明であった睪丸から集めた例 では, 2 カ月目の菌の $1 / 3$ 以下の值を示したあのああった。

H T C む表 1 に示す如く, 呼吸の場合とほぼ同様の傾 向が認められて 2 力月目の菌と 3 力月目の菌では大差が ないが，4 カ月目の菌は明らかに低值を示し 2 力月目の 菌の約 $7 / 10 ， 5$ 力月目の菌では約 $1 / 2$ であった。また乾酪化 の著明な睪丸から集菌した例では 2 力月目の菌の $1 / 3$ 以下 のものああった。

2) Catalase 活性および Peroxidase 活性

Catalase 活性は表 1 亿示す如く，個々の成績問にかな りの差が認められたが， 5 力月目の菌および乾酪化した 睪丸から集菌した菌では明らかに低值を示し， 2 力月目 の菌の約 $1 / 3$ の值を示したものああった。Peroxidase 活 性は表 2 に示す如くCatalase 活性ほど著明な差は認め, 
第 1 表 鼠癩腫の経過之集めた菌の呼吸, H T C及び Catalase 活性

\begin{tabular}{|c|c|c|c|c|c|c|c|}
\hline & 呼 & 吸 & $\mathrm{HT}$ & & Catalas & ase & \\
\hline $\begin{array}{l}\text { 接種後 } \\
\text { 月 数 }\end{array}$ & $\begin{array}{l}\mathrm{O}_{2^{-}} \\
\text {uptake } \\
\mu \mathrm{l} / 2 \mathrm{~h}\end{array}$ & \begin{tabular}{|l} 
集 \\
菌 \\
料 \\
乾酪化 \\
\end{tabular} & $\begin{array}{c}\text { 還 } \underset{\text { TTC }}{\text { 元 }} \\
10^{-9} \mathrm{~mol}\end{array}$ & \begin{tabular}{|l|}
$\mid$ 集 菌 \\
材 料 \\
乾酪化
\end{tabular} & $\begin{array}{l}\mathrm{O}_{2} \\
\text { release } \\
\mu 1 / 5 \mathrm{~min}\end{array}$ & 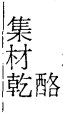 & $\begin{array}{l}\text { 菌 } \\
\text { 料 } \\
\text { 化 }\end{array}$ \\
\hline & 57.9 & & 10.1 & - & 215 & & - \\
\hline 2 力月 & 53.3 & . & 9.6 & -1 & 185 & & - \\
\hline & 47.5 & 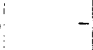 & 9.0 & - & 165 & & - \\
\hline & 52.6 & 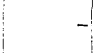 & 10.2 & 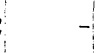 & 208 & & - \\
\hline 3 力月 & 51.8 & - & 9.4 & - & 175 & & - \\
\hline & 46.5 & - & 8.5 & - & 160 & & - \\
\hline & 38.4 & 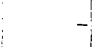 & 7.4 & 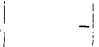 & 212 & & - \\
\hline & 34.8 & - & 6.6 & & 105 & & - \\
\hline 4 力月 & 32.1 & - & 6.5 & - & 70 & & ++ \\
\hline & 20.3 & ++ & 3.8 & ++ & 64 & & ++ \\
\hline & 29.8 & 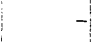 & 5.5 & 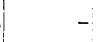 & 142 & & - \\
\hline & 27.5 & 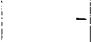 & 4.3 & & 131 & & - \\
\hline & 26.7 & + & 4.1 & + & 119 & & - \\
\hline & 16.0 & +++ & 3.0 & +++ & 62 & & ++ \\
\hline
\end{tabular}

表 2 鼠癩腫の経過と集めた菌の Peroxidase 活性

\begin{tabular}{|c|c|c|}
\hline & Peroxidase & \\
\hline $\begin{array}{l}\text { 接種 後 } \\
\text { 数 }\end{array}$ & $\begin{array}{l}\text { Purpullogalin } \\
\qquad \mathrm{g} / \mathrm{ml}\end{array}$ & $\begin{array}{l}\text { 集菌材料 } \\
\text { 乾酸化 }\end{array}$ \\
\hline 2 力月 & 64 & - \\
\hline 3 力月 & 81 & - \\
\hline & 45 & - \\
\hline 4 力月 & $\{37$ & ++ \\
\hline 5 力月 & 43 & - \\
\hline 死 菌 & 13 & \\
\hline
\end{tabular}

られなかったが， 5 カ月目の菌およで乾酪化睪丸から集 菌した菌では 2 カ月目の菌の約 $1 / 2$ の值であった。

以上の成績が示す如く, 接種後 4 力月以上経過し, 乾 酪化の著明な病巣部から集めた菌は生物学的活性が著し く低下していることが明らかになった。

\section{II 鼠瀬菌集菌法の改良}

改良の要点を述べると，感染組織をTrypsinで消化し 遠心沈澱したものでは, Ziehl-Methylen blue 染色で菌 のみが染まり組織沈渣は染まらないので一見純粋に菌の みか染められたと思われる。しかしてれを Ziehl-Nile blueで染めると組織成分がなおかなり多く含まれている ことに気付いた。そこでての Nile blue に染まる脂質 の除去法として菌の㠜集性を利し，低速遠沈法を繰返す ことによりほぼ純粋に集菌できた。その上更に菌体に附 着せる微少の細胞成分を, Adenosin monophosphatase を指標としててれを测定することによって検出し，そし ててれが除去方法には $1 / 8$ 規定苛性ソーダ液で処理するて とにより生化学的实験に使用し得る純粋菌を得たのであ る。

$$
\text { 以下その实験法之成積について述べる。 }
$$

\section{実 験方 法}

材料：鼠頡菌熊株をラットへ接種 4 力月の皮下に生

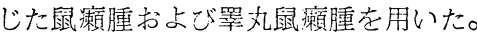

Adenosine triphosphate (ATP) は Schwarz

Bioresearch 製品を

Adenosine monophosphate (AMP) は和光純薬製

品を

Nile bulue 及び Trypsin は Merck 製品を使用した。 他の試薬は一般市販のものを用いた。

集菌法：表 3 参照

染色法：Ziehl-Nile blue 染色法, Ziehl 氏液にて1分 問加熱染色後， 1 パーセント塩酸アルコール で脱色, 水洗後 Nile blue 飽和水溶液と95パ 一セントエタノールを(2:1 V/V) の割に混 じた染色液で30秒問後染色, 水洗する方法。

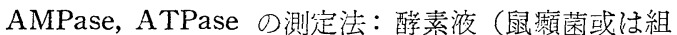
織の酚濁液） $0.5 \mathrm{ml}, \mathrm{M} / 10$ Tris 䌅衝液 $\mathrm{pH} 7.0$ $0.2 \mathrm{ml}, \mathrm{MgCl}_{2} 0.01 \mathrm{M} 0.1 \mathrm{ml}, \mathrm{kCl} \quad 0.15 \mathrm{M} 0.1$ $\mathrm{ml}$, 基質 $6 \% \mathrm{~mol} 0.1 \mathrm{ml}$, 全量 $1 \mathrm{ml}$ とし, $37^{\circ} \mathrm{C}$ に60分閐 incubateし, 遊離した無機燐を Lowry and Lopez ${ }^{10)}$ の方法により定量した。 3 ?過塩素酸 $0.5 \mathrm{ml}$ を加え遠沈除蛋白し,上清 に 0.1 規定醋酸ソーダを $5 \mathrm{ml}$ 加え $\mathrm{pH} 4.0$ 附 沂にし,VitamineCの1 \% 水溶液を $1 \mathrm{ml}$, およ び $1 \%$ モリブデン酸アンモニウムの0.05規定 䟽酸溶液を $1 \mathrm{ml}$ 加え, $\mathrm{pH} 4.0$ の醋酸緩衝液を 穧几てて全量を $10 \mathrm{ml}$ として室温に10分問放置

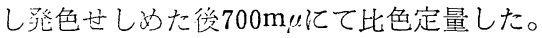
贸験のたびごとに Blank および無機燐の 刘照をとった。乾燥重量は比濁計の Optical Density より計算した。比色計および比濁計 は Coleman Junior を用いた。

ラウリン酸脱水素醉素活性の測定法：酢素液（鼠瀬菌 の惩濁液） $0.5 \mathrm{ml}, \mathrm{M} / 10$ Tris 緩衙液 $\mathrm{pH} 7.0,0.4$ 
$\mathrm{ml}, \mathrm{M} / 10$ 燐酸緩衝液 $\mathrm{pH} 7.00 .1 \mathrm{ml}$, Sodium Laurate $0.5 \mathrm{ml} 5 \times 10^{-6} \mathrm{~mol} 0.6 \%$ Tween 水溶 液, Triphenyl tetrazolium chloride(TTC) $0.5 \mathrm{ml} 5 \times 10^{-5} \mathrm{~mol}$, 全量 $2 \mathrm{ml}$ とし, Thunberg 管にて嫌気的条件下 $37^{\circ} \mathrm{C} に 6$ 時間 incubate す。形成された Formazan を醈酸エチルの $5 \mathrm{ml}$ に抽出し，480m "! にて Beckmann 光電 分光々度計にて㠿色定量した。

B C G：ソートン培地に境養 2 週間目の菌体(刘照菌) を用いた。

\section{実 驗 成 纈}

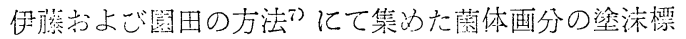
本它Ziehl-Methylene blue 染色方ると，図Iに見られ るように Metrylene blue に青く染志乃部分がなく藏 ばかりのように見えたが，Ziehl-Nile blue 染色在する

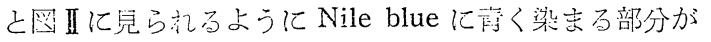

なおかなりの量見汕された。しかるに $900 \times g$ にて遠沈 洗滌考繰返してえられた菌体画分では，図亚に見られる 9うに Methylene blue には勿論, 図IVに見られるよう に Nile blue にても青く染まる部分は認められなかっ た。

Ziehl-Nile blue 染色法によって殆ど青く深まる部分 がみられない菌体画分のATPase および AMPase 活性 を測定すると表 4 の無処理の欄に示す如くかなり強い活 性を示した。しかしてのATPase およびAMPase 活性 を示方成分は微量に混在する組織成分による屯のではな いかと考え，健常ラットの睪丸を表 5 に示す集菌法と同 様に操作して，微量の組織成分を得た。この組織成分は 集菌操作のときに菌体画分の中に泚入してくる成分であ るが，非常に強い ATPase および AMPase 活性を示し た。ここで純培着した BCG 交刘照として組織成分に由白 来引るATPase および AMPase 在失活さしめるが，菌

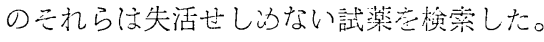

第 3 表 国灌菌の改良集菌法

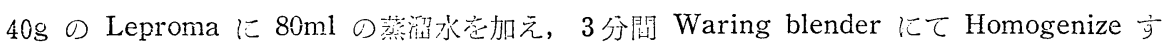
$900 \times \mathrm{g}$ 亿て 5 分䧋遠沈

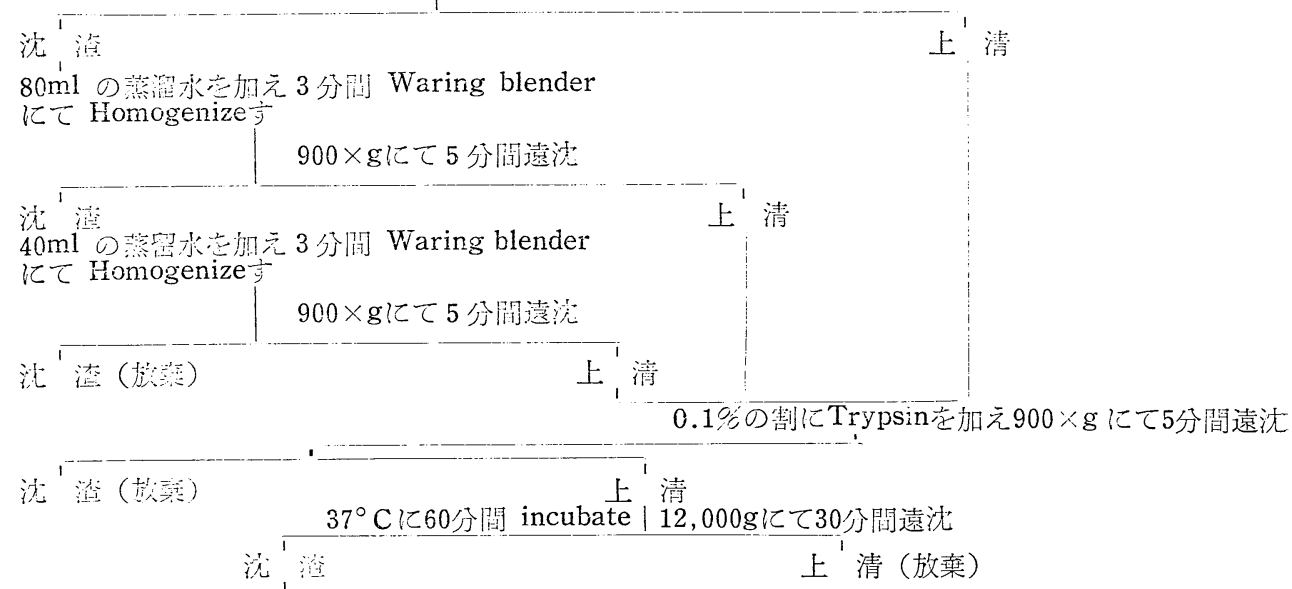

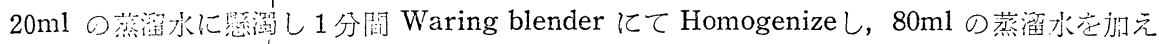

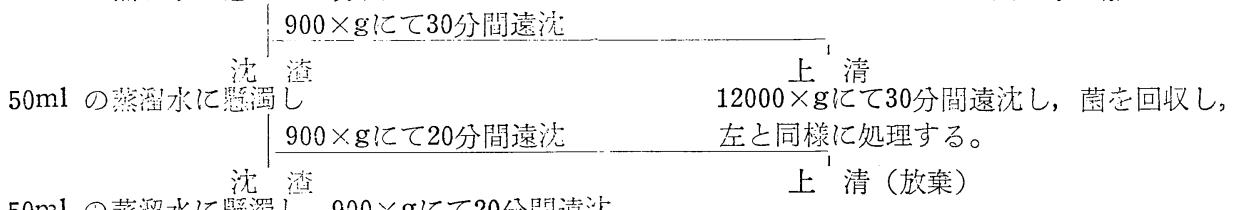

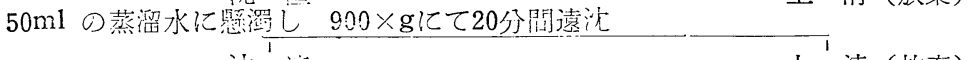

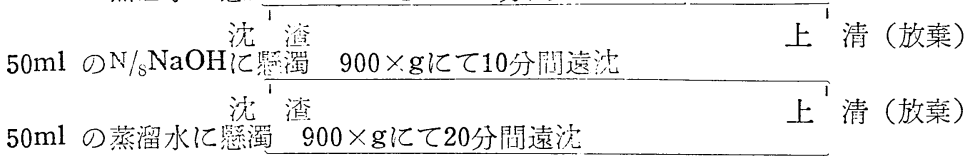

$50 \mathrm{ml}$ の蒸溜水に賏濁 $900 \times \mathrm{g}$ 亿て 20 分間遠沈

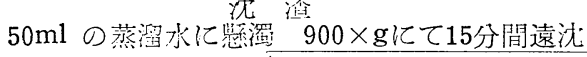

上'清（放棄）

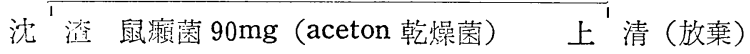


西村, 伊藤，森，高坂論文附図

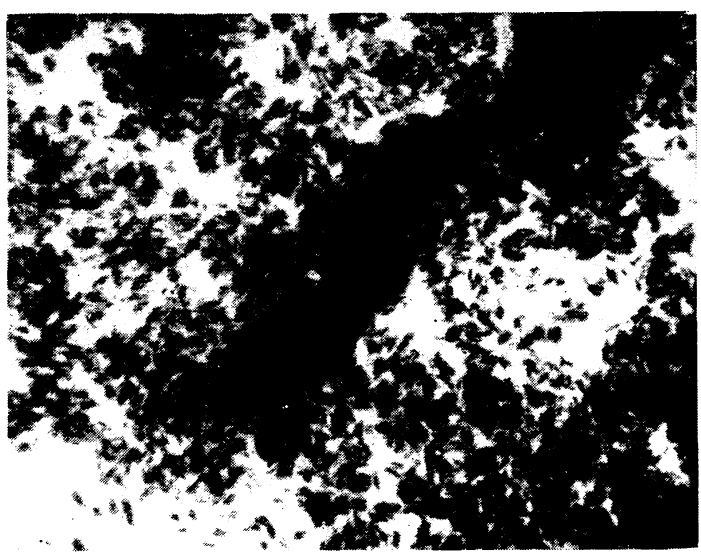

瓦 I

峛速遠心により集めた落体

Ziehl-Neelsen 染色

緑色フィルター $(560 \mathrm{~m} \mu)$ を

用いて撮影

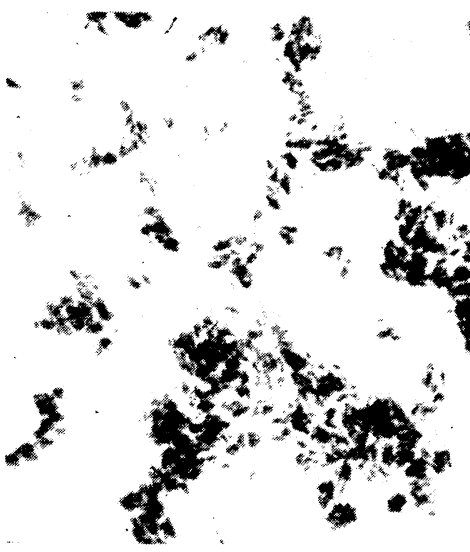

図 III

低球遠心により集めた菌体

Ziehl-Neelsen 染色。

緑色フィルター $(560 \mathrm{~m} \mu)$ を

用いて撮影

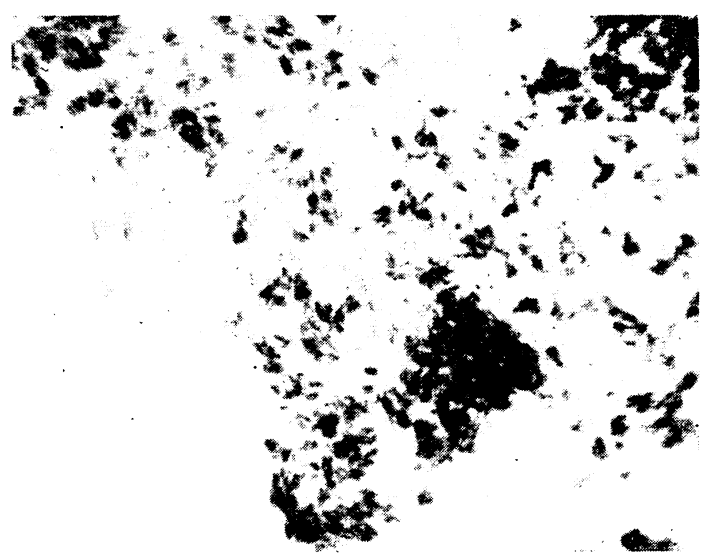

区 II

高速遠心により集めた菌体 Ziehl-Nile blue 染色 緑色フィルター $(560 \mathrm{~m} \mu)$ を 朋いて撮影

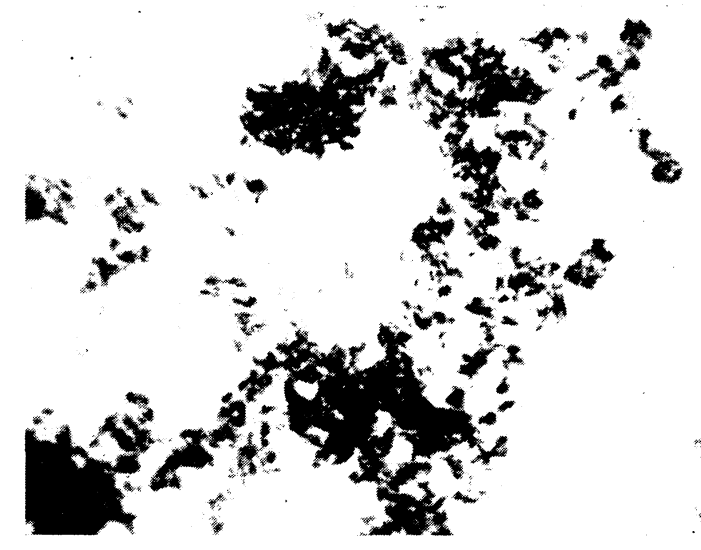

図 IV

低速遠心により集めた菌体 Ziehl-Nile blue 染色

緑色フィルター $(560 \mathrm{~m} \mu)$ を 用いて撮影 
第 4 表 試薬処理した組織成分の ATPase, AMPase 活性

\begin{tabular}{|c|c|c|c|}
\hline 組織成分 & 基質 & 乾燥重量 mg & $\begin{array}{c}\text { 遊離無機燐 } \\
\mu \mathrm{g} / \mathrm{mg}, \mathrm{hr}\end{array}$ \\
\hline \multirow[b]{2}{*}{ 無処 理 } & $\mathrm{ATP}$ & 0.48 & 30 \\
\hline & AMP & 0.48 & 226 \\
\hline $\begin{array}{l}\text { Sodium des- } \\
\text { oxy-cholate }\end{array}$ & ATP & 0.34 & 12 \\
\hline 処 理 & AMP & 0.34 & 0 \\
\hline $\mathrm{N} / 4 \mathrm{NaOH}$ & ATP & 0.15 & 0 \\
\hline 処理 & AMP & 0.15 & 0 \\
\hline $\mathrm{N} / 8 \mathrm{NaOH}$ & ATP & 0.15 & 0 \\
\hline 処 理 & AMP & 0.15 & 0 \\
\hline
\end{tabular}

第 5 表 試薬処理した BCG のATPase, AMPase 活性

\begin{tabular}{|c|c|c|c|c|c|}
\hline $\mathrm{BCG}$ & 基質 & 乾焼重量mg & \multicolumn{3}{|c|}{$\begin{array}{l}\text { 遊離無機燐 } \\
\mu \mu \mathrm{g} / \mathrm{mg}, \mathrm{hr}\end{array}$} \\
\hline & ATP & 1.58 & & & 13 \\
\hline 鮰 処 埋 & AMP & 1.58 & & & 6 \\
\hline $\begin{array}{l}\text { Sodium des- } \\
\text { oxy-cholate }\end{array}$ & ATP & 1.46 & & & 9 \\
\hline & AMP & 1.46 & & & 5 \\
\hline $\mathrm{N} / 4 \mathrm{NaOH}$ & ATP & 1.40 & & & 13 \\
\hline 処 理 & AMP & 1.40 & & & 7 \\
\hline $\mathrm{N} / 8 \mathrm{NaOH}$ & ATP & 1.42 & & & 13 \\
\hline 処 理 & AMP & 1.42 & & & 7 \\
\hline
\end{tabular}

第 6 表 感染組織より集菌した鼠癩菌体画 分の ATPase, AMPase 活性

\begin{tabular}{|c|c|c|c|}
\hline $\begin{array}{l}\text { 鼠 攋 } \\
\text { 芬分 }\end{array}$ & 基 質 & 乾燥重量mg & $\begin{array}{c}\text { 遊離無機燐 } \\
\quad \mathrm{kg} / \mathrm{mg}, \mathrm{hr}\end{array}$ \\
\hline \multirow{2}{*}{ 無 処 玨! } & ATP & 1.9 & 8 \\
\hline & $\mathrm{AMP}$ & 1.9 & 15 \\
\hline $\mathrm{N} / 8 \mathrm{NaOH}$ & ATP & 1.7 & 0 \\
\hline 処 理 & $\mathrm{AMP}$ & 1.7 & 0 \\
\hline
\end{tabular}

第 7 表 $\mathrm{N} / 8 \mathrm{NaOH}$ 処理菌之非処理菌之の Lauric acid dehydrogenase 活性

\begin{tabular}{|c|c|c|c|}
\hline $\begin{array}{l}\text { 鼠癩 } \\
\text { 菌体婳分 }\end{array}$ & 基 質 & 乾燥重量 mg & $\begin{array}{l}\text { Formazan } \\
\mathrm{mol} / \mathrm{mg}, \mathrm{hr}\end{array}$ \\
\hline \multirow{2}{*}{ 筙 処 理 } & \multirow{2}{*}{$\begin{array}{l}- \\
\text { Sodium } \\
\text { Laurate }\end{array}$} & 7.15 & $4 \times 10^{-9}$ \\
\hline & & 7.15 & $23 \times 10^{-3}$ \\
\hline \multirow{2}{*}{$\begin{array}{l}\mathrm{N} / 8 \mathrm{NaOH} \\
\text { 処 理 }\end{array}$} & \multirow{2}{*}{$\begin{array}{l}- \\
\text { Sodium } \\
\text { Laurate }\end{array}$} & 7.07 & $4 \times 10^{-9}$ \\
\hline & & 7.07 & $23 \times 10^{-9}$ \\
\hline
\end{tabular}

1 規定硫酸は組織成分のATPase および AMPase を完 全に失活せしわるが，BCGのATPase および AMPase あ同様に完全に失活せしめるので不適当であり,Sodium cholate は組織成分の ATPase 及び AMPase を完全に 失活せしめないのでやはり不適当であった。表 4 および 表 5 に示す如くSodium Desoxycholate の $10^{-2} \mathrm{M}$ 水浴 液に室温で一時间処理する方法および $1 / 4$ 規定苛性ソーダ 或は1/8規定苚性ソーダに室温で10分肅処理する方法がや や適当な成績を示した。菌に対する障害の最も少い上考 えられる $1 / 8$ 規定封性ソーダに室温で10分閒処理した後, 蒸留水で 2 回遠沈洗滌する师泛を選び，表 6 亿示す如く 集菌された菌体画分の無処理群と $1 / 8$ 規定アルカリ処理群 とにおいて各々のATPase 及び AMPase 淣性を測定し た。䒜処理の菌体画分にはなおかなり強い活性を認めた が，アルカリ処理の菌体画分には全然活性を認めなかっ た。

為政抢よび堤 ${ }^{11)}$ は臼瀬菌によるラウリン酸の脱水素酵 素をT T Cの還元により観察しているので, 著者は国獺 菌をアルカリ処理することによりラウリン酸脱水素酵素 が失活するか否かを测定した。表 7 に見ら机るようにア ルカリ処理した菌体画分之與処理の菌体画分との阔にラ ウリン酸脱水素酵素活性の差は認められなかった。

\section{考察}

（I）形態学讪にチール氏フクシンで染色したスメア について見ても, 新鮮な Leproma 中の菌は, 細胞質が 平等に濃く染み，菌も長大であるが陳旧な硬化した Leproma や乾酪化した病单から得た状では細胞質が不 平等に染み，短小で連鎖球菌状または顆粒状型をなすも のが比較们多い。菌の企:物学的活性が新鮮な Leproma から得た菌に強く，4 力月以上を経過した睪丸瀬腫殊に 乾酪化した病巣から待た菌において極めて低かったてと は，上記の形態学们所見とよく一致している。そ机故 に, 物質代謝の尖験に供する菌は少くとも睪丸接種 2 3 力月の新鮮な鼠瀬腫を材料として集菌しなければなら $ぬ_{0}$

（II）低速遠沈により大きな組織塊を除いた上清けに は組織細胞のミトコンドリア，マイクロゾームおよびそ の他の組織残滰が含ま机ている。これらのものはリポ蛋 白質を多量に含む有形体であるため，Trypsin 消化によ って完全に消化溶解することは引来ない上考えられる。 Trypsin消化したのち 10,000r.p.m にて遠沈集菌する伊 籐および園H $H^{7}$ のう法では，えられた菌体画分中にミト コンドリアが混入してくる。この混入したミトコンドリ アは恐らくTrypsin消化を受けて methylene blue に親 
和性の部分が破壊されたため, こ机に染まらなくなった のであろうが, Nile blue は lipid に親和性があるので Trypsinに消化されない部分静く染めることが出来た ので尚ろう。

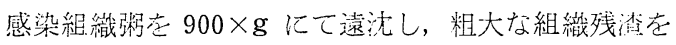
除いた上清在更に $900 \times \mathrm{g}$ にて嗃沈集萝するには次のよ

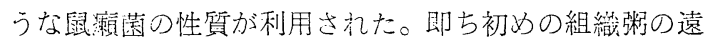

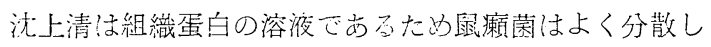
ていて,900×gの遠沈によっては沈降しにくいが, 12,000

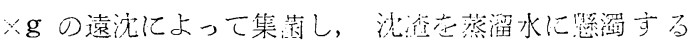

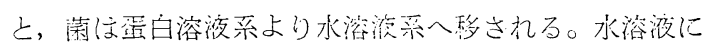

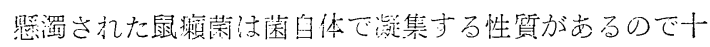

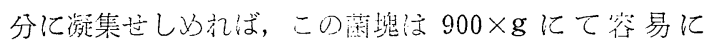

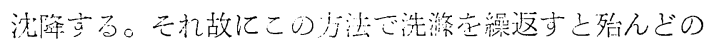

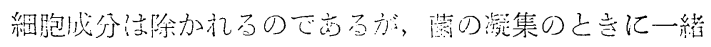

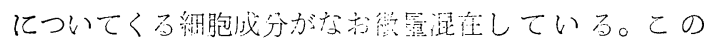

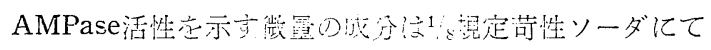

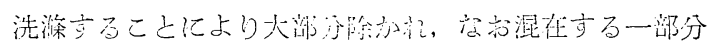
もアルカリのたるに破搷芯沉る。

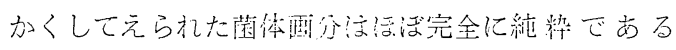

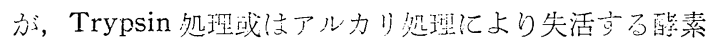

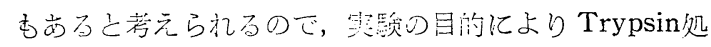
理或! アルカリ処理を省略して集菌守る必要があると思

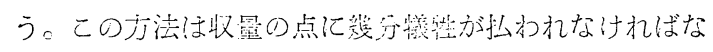
らない。

Gessler 等12-13) Freon $112\left(\mathrm{CCl}_{2} \mathrm{~F}-\mathrm{CCl}_{2} \mathrm{~F}\right)$ および Genetron $226\left(\mathrm{CF}_{2} \mathrm{Cl}-\mathrm{CCl}_{2} \mathrm{~F}\right)$ を用いウイルスを集婂 いるが，こ机らの溶媒はウイルスに対する陵害作用が非 常に少い之報告されている。著者等む DaifronS III $\left(\mathrm{CCl}_{2}\right.$ $\mathrm{FCCl}_{2} \mathrm{~F}$ ) を用(感染皮下枋よざ睪丸国㾋腫から集菌を試 みたが，組織成分の混入が各くて利用するまでに至らな かった。

\section{緒 論}

1）鼠瀨䓟物質代謝の实験に使用する新鮮にして酸素 活性の強い菌を得るために往ラット睪丸接種 $2 \sim 3$ カ月 の Leproma が適当である。

2）菌の純粹度老検定方方方法として，

Ziehl-Methylen blue で染色できなかった組織成分を Nile blueによって検出し, Nile blueで証明できなかっ た組織細胞成分を, Adenosine mono-phosphatase を測 定する方法で証明した。

3）集菌画分中に混在せる Nile blue 可染物質は低 速遠心で沈激を繰返すととにより, Adenosine monophosphatase 活性を示す微量の細胞成分は $1 / 8$ 規定苛性ソ
ーダで処理することにより完全に除去できた。

(この論文の英文篇は谷村忠保教授古稀記念諭文集に揭 載された。)

\section{文献}

1）西村萁二，本多一：癩菌の培養に関する研究（其 の1）中村, 遠䓠氏牛顎下腺Mucin培地による瀬菌,

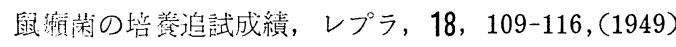

2）西村真二, 本多一: 癩菌の培䔲に関する研究(II) 中村氐 Mucin 培楸追試成領第 2 報, レプラ，20，9297 (1951)

3）谷村忠保, 西村真二, 本多一, 児玉正檤：整菌の

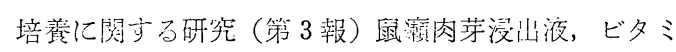
ン, 諸種のAmino 酸, Sphingomyelin 添河培地泣に

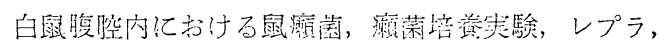
23, 319-326 (1954)

4) Hanks, J. H. : Measurenient of the hydrogen transfer capacity of MYCOBACILZIA. J. Bact. 62: 521-528 (195i)

5) Nakamura, IM. : Attempts to approach to the clarification of chemical composition of Mycobacterium lepae murium. (III) Chemical composition of the bacilli separated from the subcutaneous tissue of rat infected with Mycobacterium leprae murium by pretreatment with trypsin. Kurume Med. J. 3, 133-145 (1956)

6) Lew, J. and Carpenter, C. M.: The separatior of M. Ieprae from tissues by enzyme digestion Am. Rev. Tuberc. 74, 152 (1956)

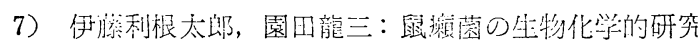

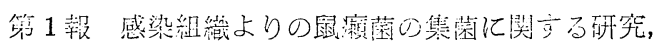
レブラ, 26, 141-143 (1957)

8) Tanimura, T., Ito, T. and Sonoda, R.: On the enzymic activities of murine leprosy bacillus. 谷村教嗳古挤記念諭文等 (1961)

9) Hedgecock, L. W. and Faucher, I. O.: Retatior of pyrogallol-peroxidative activity to isoniazic resistance Mycobacterium tubereulosis. Am. Rev Tuberc., 75, 670-694 (1957)

10) Lowry, O. H. and Lopez, J. A.: The determin ation of inorganic phosphate in the presence 0 labile phosphate esters. J. Biol. Chem. 162, 421 428 (1946)

11) Tamemasa, O. and Tsutsumi, S.: On the meta bolism of Mycobacteria. I. Dehydrogenase activi 
ties of Mycobacterium leprae murium. Japan. J. Exper. Med. 28, 183-197 (1958)

12) Gessler, A. E., Bender, C. E. and Parkinson, M. C.: A new and rapid method for isolating viruses by selective fluorocarbon deproteinization. The New York Academy of Science Ser. II, 18, No.8,
701-703 (1956)

13) Gessler, A. E., Bender, C. E. and Parkinson, M. C. : Animal viruses isolated by fluorocarbon emu1sification. The New York Academy of Science Ser. II, 18, No. 8 707-717 (1956) 